\title{
Review
}

Maria Clara Martinelli*, Mauro Coltelli, Marco Manni, Letizia Bonizzoni, Alessandra Guglielmetti, Massimo Oddone, Maria Laura Balestrieri

\section{Prehistorical Obsidian Sources in the Island of Lipari (Aeolian Islands)}

https://doi.org/10.1515/opar-2020-0119

received July 2, 2020; accepted November 5, 2020.

\begin{abstract}
This research project concerns the study, analysis and dating of obsidian flows on the island of Lipari, in relation to the population of the Aeolian Islands, during the Neolithic period.

The collection, processing and diffusion of Lipari obsidian characterise the Neolithic population of Lipari and the entire Mediterranean. By improving the knowledge of supply methods in the territory, it will be possible to formulate hypotheses on the chronology of the sources, the ways of collecting the raw material and on the mobility of the Neolithic communities in the Aeolian Islands. The scientific research is divided into two main topics: the first concerns the analytical and methodological aspects of archaeological and geological studies of Lipari obsidian; the second, the formation of obsidian at Lipari, their sources and lithological characteristics. Throughout the duration of this study we will perform new age determinations of Neolithic obsidian artefacts and geological samples, directly with the method of fission track, and indirectly dating paleo soils using the radiocarbon method.
\end{abstract}

Keywords: Aeolian islands, obsidian, fission-track dating

\section{Introduction}

The present work is part of the wider project, "Lipari obsidian and Neolithic human communities in the Aeolian islands" whose purpose is the study of the connection between obsidian flows from Lipari Island and the Neolithic populations of the Aeolian Archipelago (Italy) (fig. 1). The study started in 2018 in collaboration with several research Italian institutes and is divided into four main areas:

1) History of archaeological studies on the Lipari obsidian;

2) Sampling and analysis of supply sources: chemical analysis through NAA (neutron activation analysis) and XRF (X-ray fluorescence spectroscopy) technique; dating with fission-track method;

3) Sampling and analysis of obsidian tools used by the Aeolian Neolithic settlements: chemical analysis through NAA and XRF techniques; dating with fission-track method;

4) Radiocarbon dating of charcoals remains in layers from Neolithic settlements.

The project is in progress, therefore we discuss a preliminary report.

Article note: This article is a part of Special Issue 'The Black Gold That Came from the Sea. Advances in the Studies of Obsidian Sources and Artifacts of the Central Mediterranean Area', edited by Franco Italiano, Franco Foresta Martin \& Maria Clara Martinelli.

*Corresponding author: Maria Clara Martinelli, Parco Archeologico delle Isole Eolie, Museo Luigi Bernabò Brea, via Castello 2, Lipari, Italy, E-mail: martinellimariaclara@gmail.com

Mauro Coltelli, Marco Manni, Istituto Nazionale di Geofisica e Vulcanologia, Osservatorio Etneo, Piazza Roma 2, 95125 Catania, Italy Letizia Bonizzoni, Alessandra Guglielmetti, University of Milan, department of Physics “Aldo Pontremoli”, via Celoria 16, 20133 Milano, Italy Massimo Oddone, University of Pavia, Department of Chemistry, Via Taramelli 12, 27100 Pavia, Italy

Maria Laura Balestrieri, IGG-CNR, Via G. Moruzzi 156124 Pisa, Italy 


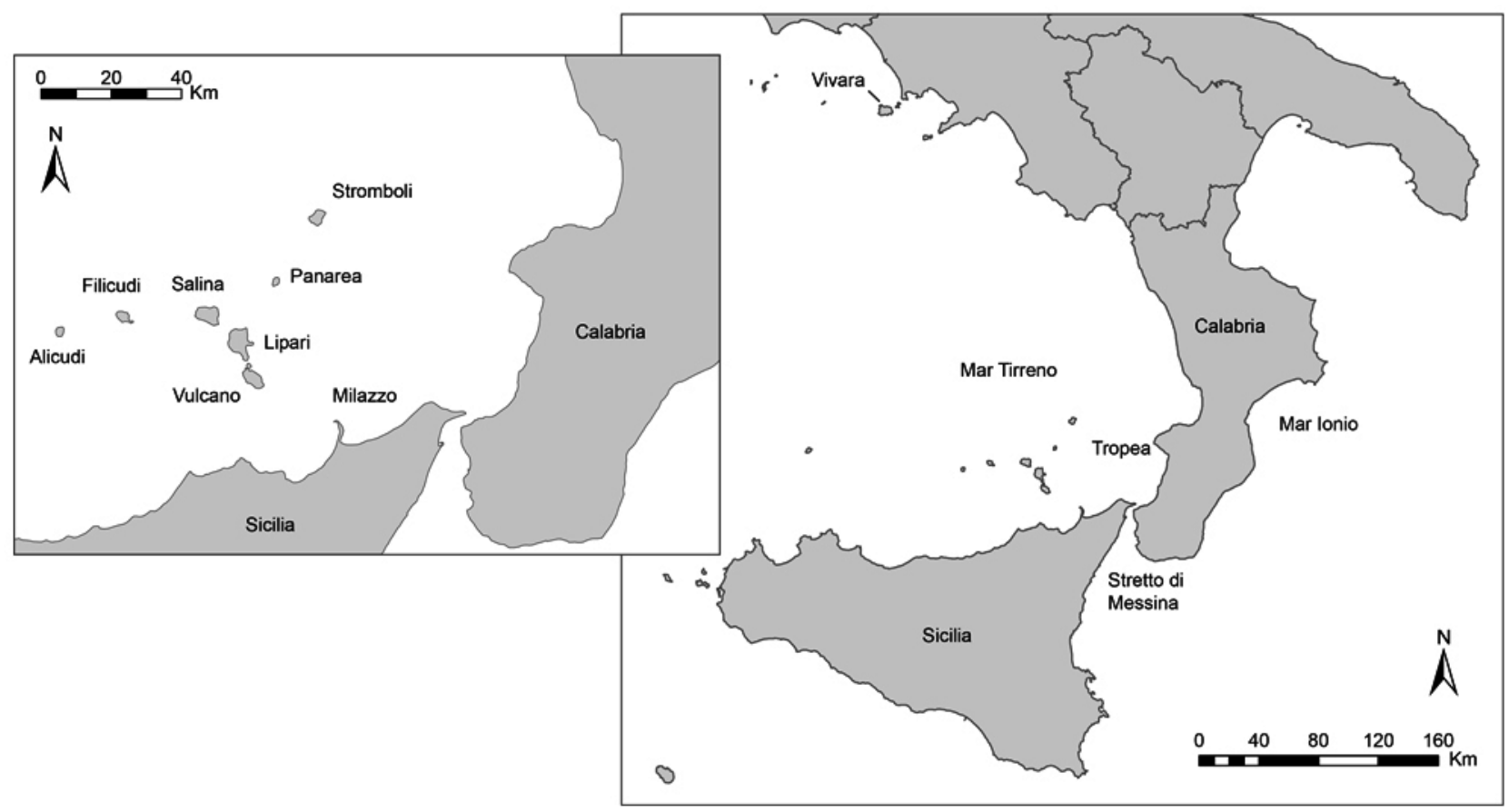

Figure 1: Localization of Aeolian archipelago in southern Tyrrhenian Sea.

\section{Obsidian of Lipari}

The first geological-archaeological study of the obsidian from Lipari was carried out by the German archaeologist Giorgio Buchner, who identified the main obsidian flows as correlated with the oldest human settlements of the Aeolian islands (Cavalier, 1997). In 1949 Buchner published a work on the Mediterranean obsidian, where the chronological problems about Rocche Rosse, Forgia Vecchia and Vallone del Gabellotto flows of Lipari are described, and concerning the latter, he referred to the name "Pomiciazzo". By the observation of the Papesca's stratigraphy in Canneto, he discovered that this flow is older than those of Rocche Rosse and Forgia Vecchia. As a result he suggested that the occurrence of an even older flow lower to the pumice layer erupted by Gabellotto-Pomiciazzo, and is visible only on the coast along the Campo Bianco, which has been named Capo Rosso flow on the Lipari geological map.

Buchner performed test pits in the Papesca area, and discovered a paleo soil formed by darkish brown soil with fireplaces and many traces of the obsidian knapping. During a further visit with Luigi Bernabò Brea, Buchner (1949) found a fragment of pottery with reddish surfaces attributable to Neolithic ceramic of the Diana facies. In the meantime, the archaeological research in the archipelago became systematic with the presence of the archaeologists Luigi Bernabò Brea and Madeleine Cavalier. At the same time, geological knowledge was updated due to the new surveys Hans Pichler and Jorg Keller (Keller, 1967) drafted of the Aeolian geological maps of the CNR International Institute of Volcanology. Lipari was completed in 1976 (Pichler, 1976).

During research carried out in 1969, Keller (1970), identified another prehistoric obsidian collection and knapping area on the north side of the Vallone del Gabellotto during the construction of the Canneto-Lami road. Human activity was recognised in a yellowish layer with many obsidian debris, blades and splinters, lying above another layer composed of obsidian stones. Cavalier (1979) compared archaeological and volcanological data in order to indicate the possible chronology of the obsidian flow exploited by human communities in the Neolithic period. The scholar supposed that the quarry identified by Keller could be easily reached by the people from the Neolithic settlement of Castellaro (Quattropani), through a passage between Colle Sant'Elmo and Monte Chirica.

Thus dating the obsidian flows became a priority and as such, Giulio Bigazzi focused his efforts in the creation of a new laboratory of Nuclear Geology for fission-track dating, in the framework of the Institute of Geochronology and 
Geochemistry and Isotope of the CNR in Pisa (Bigazzi et al., 1971; Arias-Radi et al., 1972; Bigazzi \& Bonadonna, 1973; Bigazzi et al., 1992).

The first investigations include the comparison between the Italian obsidians from Palmarola, Monte Arci (Sardinia), Pantelleria and Lipari. The results show that this method (fission-track) is relatively reliable for those from Lipari and Pantelleria, as both are too recent to apply the K-Ar dating method. K-Ar dating, at least since work back in the 1980s (Ar-Ar), is reasonable for the Pantelleria time range, but not for Lipari.

The volcanic unit of Vallone del Gabellotto-Fiume Bianco, according to Cortese et al. (1986), represents the origin of pumice and obsidian occurring in the north-east part of Lipari Island when Neolithic communities began to collect raw materials (fig. 2). Pomiciazzo obsidian lava flow originated from the eastern edge of the Vallone del Gabellotto crater, which reached the north-eastern coast of Lipari in the area corresponding to the Spiaggia della Papesca and continued under sea level for a total length of $4.5 \mathrm{~km}$ (Gamberi \& Marani, 1997). The dispersal of pyroclastic products was described by Cortese et al. (1986). Age determination of the obsidian flow, performed by Giulio Bigazzi and Francesco Bonadonna, in the Nuclear Geology laboratory for fission-track dating, was 11.4 ka (Bigazzi \& Bonadonna, 1973).
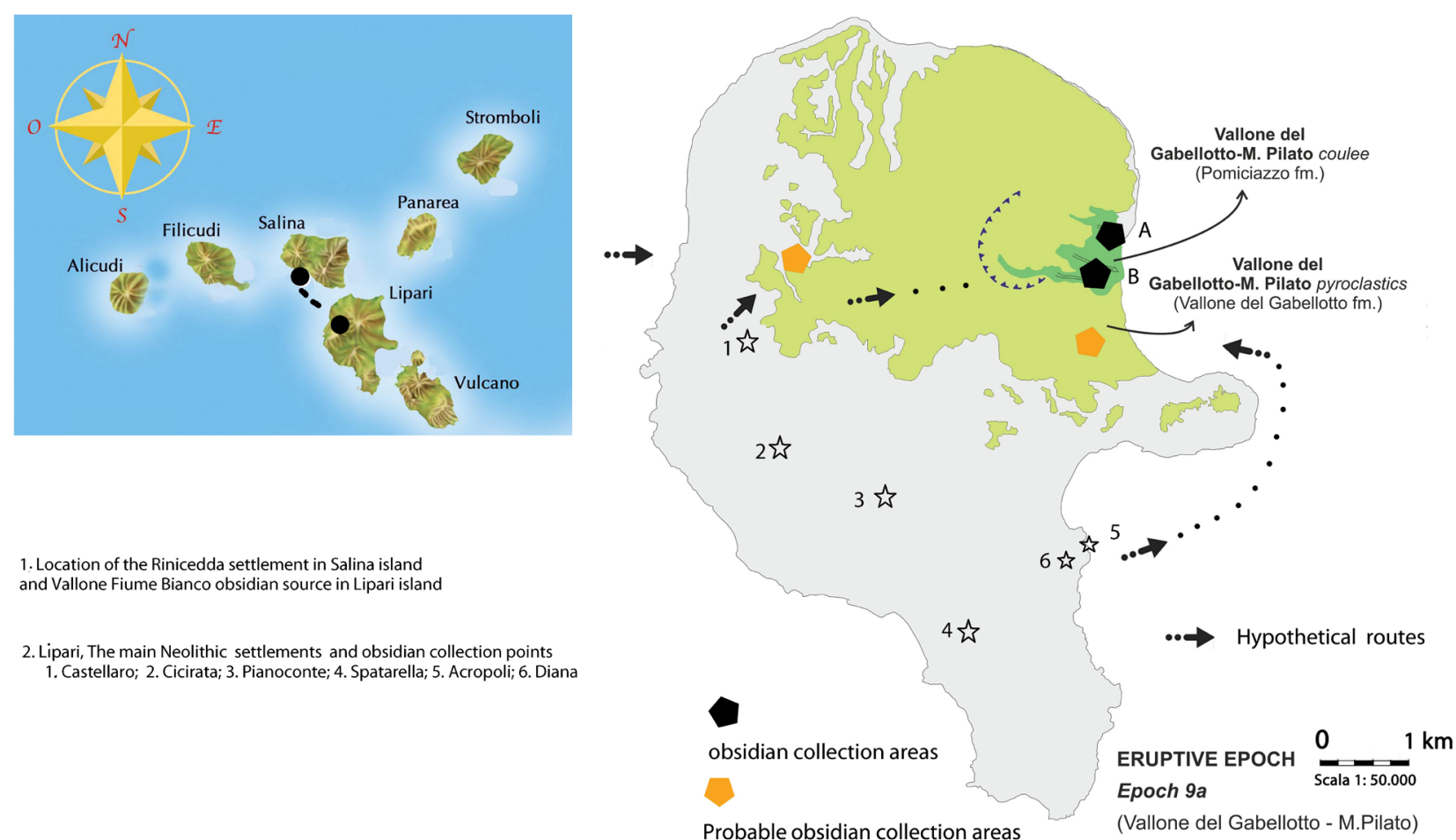

Figure 2: Lipari. Neolithic settlements and probable obsidian collection areas. In black the collection site of Papesca (A) and Lami (B). (Redrawn after Forni et al., 2013).

Concerning the lava flow of Pomiciazzo, Pichler proposed an age of about 9500 BP years based on the average between two dates: $11400 \pm 1800$ BP and $8300 \pm 830$ BP (Cavalier, 1979, p.118). Successively, other age determinations were performed: 8.6 ka (Wagner et al., 1976); 8.6 ka (Arias et al., 1986). In more recent studies Forni et al. (2013) referred the same obsidian flow to an age of $8.6 \mathrm{ka}$, according to the age of 8.7-8.4 ka obtained through radiocarbon dating of foraminifers included in the coring, carried out in the Adriatic Sea where a tephra layer had been deposited during the eruption of Vallone del Gabellotto of Lipari (Zanchetta et al., 2011).

Another obsidian's dating from fission-track concerns a sample coming from the pumice and obsidian deposits of the Vallone del Gabellotto eruption in the Vallone Fiume Bianco, about $1 \mathrm{~km}$ from Monte Chirica (Bigazzi, Coltelli, \& 
Norelli, 2003). Its age of $5650 \pm 530$ corrected to $7170 \pm 720$ (7.17 ka) suggests that the Vallone Gabellotto eruption is more recent than that inferred by Forni et al (2013).

In the Canneto Dentro area, the pyroclastic fall deposits of Vallone del Gabellotto formation (Forni et al., 2013) are visible and mostly composed of angular pumice clasts and clean obsidian blocks. Unfortunately they have not been dated yet.

Since the 1970s, archaeological studies focused both on the methods to determine the provenance of obsidian and to reconstruct the trade routes of this important raw material through the spread of volcanic glass artefacts in prehistoric settlements (Tykot, 2017). In addition to fission-track dating, the geochemical analysis of trace elements began to be applied to obsidian artefacts and geological samples for the identification of the source of origin (Bigazzi, Oddone, \& Radi, 2005). From 1964 (Cann \& Renfrew, 1964; Belluomini, 1972) until now, several geochemical methods have been used to identify the provenance of obsidian. The most common are those based on X-ray spectrometry: XRF-WD and SEM-EDS (Acquafredda et al., 1999, 2006, 2018; Tykot, 1996, 1998, 2002a, 2002b), neutron activation analysis NAA (Bigazzi et al., 1986) and, recently, plasma mass spectrometry ICP-MS is used (Barca et al., 2007).

The research has significantly expanded involving an increasing number of prehistoric sites (Tykot, 2004, 2018). In fact, since the oldest facies of the Italian Neolithic, obsidian tools are common among the lithic instruments found in settlements. The determination of the obsidian source allowed to develop distribution maps for a better understanding of the trade of resources within the Mediterranean during the Neolithic period (Tykot et al., 1997, 2013). Unfortunately, in the Lipari context it is not easy to find the area of obsidian extraction because the north-eastern part of the island has been largely destroyed by recent volcanic eruptions. However, in the stratigraphy of the narrow Vallone del Gabellotto gorge, corresponding to the southern boundary of the Pomiciazzo lava, portions of paleo soils with obsidian artefacts can be found as a trace of Neolithic sites (Bigazzi et al., 2005; Keller, 1970; Buchner, 1949).

\section{Neolithic Settlements and Obsidian}

The archaeological data (Martinelli \& Lo Cascio, 2018) shows that the Aeolian Islands began to have stable human frequentations starting from the Neolithic with the facies of Stentinello (5500-5000 BC), characterised by impressed and painted pottery. This facies is widespread across Sicily and Calabria, and likely represents the regions of origin of the first inhabitants of the archipelago. Two settlements have been found: Castellaro on Lipari (Cavalier, 1979; Nomi \& Speciale, 2017) and Rinicedda on Salina (Bernabò Brea \& Cavalier, 1995). Furthermore, findings of impressed pottery fragments are attested at two other settlements on Lipari: the first localised in Contrada Diana from the excavation of trench XVII (Bernabò Brea \& Cavalier, 1960), the second in Cicirata, an inner locality near Pianoconte (Martinelli \& Lo Cascio, 2018). During the Neolithic period small groups of people lived in structures built from perishable materials as evidenced by the fragments of hut plaster with prints of thin wood. From this time the habitation of Lipari becomes constant and extends over time throughout the Neolithic period, with the succession of different facies from 5500 to $4000 \mathrm{BC}$. The settlement develops mainly on the Rocca di Lipari, where one of the most complete stratigraphies of prehistory in the Mediterranean is attested. For about five hundred years, the facies of trichromic pottery and successively that of Serra d'Alto implement control over the island where the rich raw material source is located. In the Late Neolithic period, during the facies of Diana (4500-4000 BC), a territorial expansion occurs with the establishment of small settlements on the other islands of the archipelago, while the largest settlement is in Contrada Diana (Lipari). The Late Neolithic period is characterised by a technology specialized in obsidian knapping for blades production (Martinelli et al., 2019) and also by the greater diffusion of the Lipari obsidian in the Mediterranean area. In addition to the typological characterisation of the artefacts to understand the operational chain of working and using of tools, archaeologists focused their attention on the methods of transport, the presence of collection centres, the preparation of obsidian core and blades that have been found in the sites far from their original source. The practical and/or magiccultural value of this raw material was subject to debate. 


\section{Sampling Methods}

The sampling (fig. 3) was conducted in March 2018, as well as October and May 2019, and was shared in two groups: 1) Geological, with the location through geographical coordinates of each sample; 2) Archaeological, with the selection of obsidian artefacts from Neolithic sites. The first group (fig. 4; tab. 1) includes obsidian blocks collected in the pyroclastic deposits of Vallone del Gabellotto in Vallone Fiume Bianco (LIP6 and LIP4); Canneto Dentro (LIP3) and Vallone del Gabellotto (LIP8) pyroclastic deposits; from Pomiciazzo lava flow (LIP7); obsidian fragments collected by pyroclastic deposits of Monte Guardia succession, relating to volcanic phase dated around 27-24 ka (Forni et al., 2013).

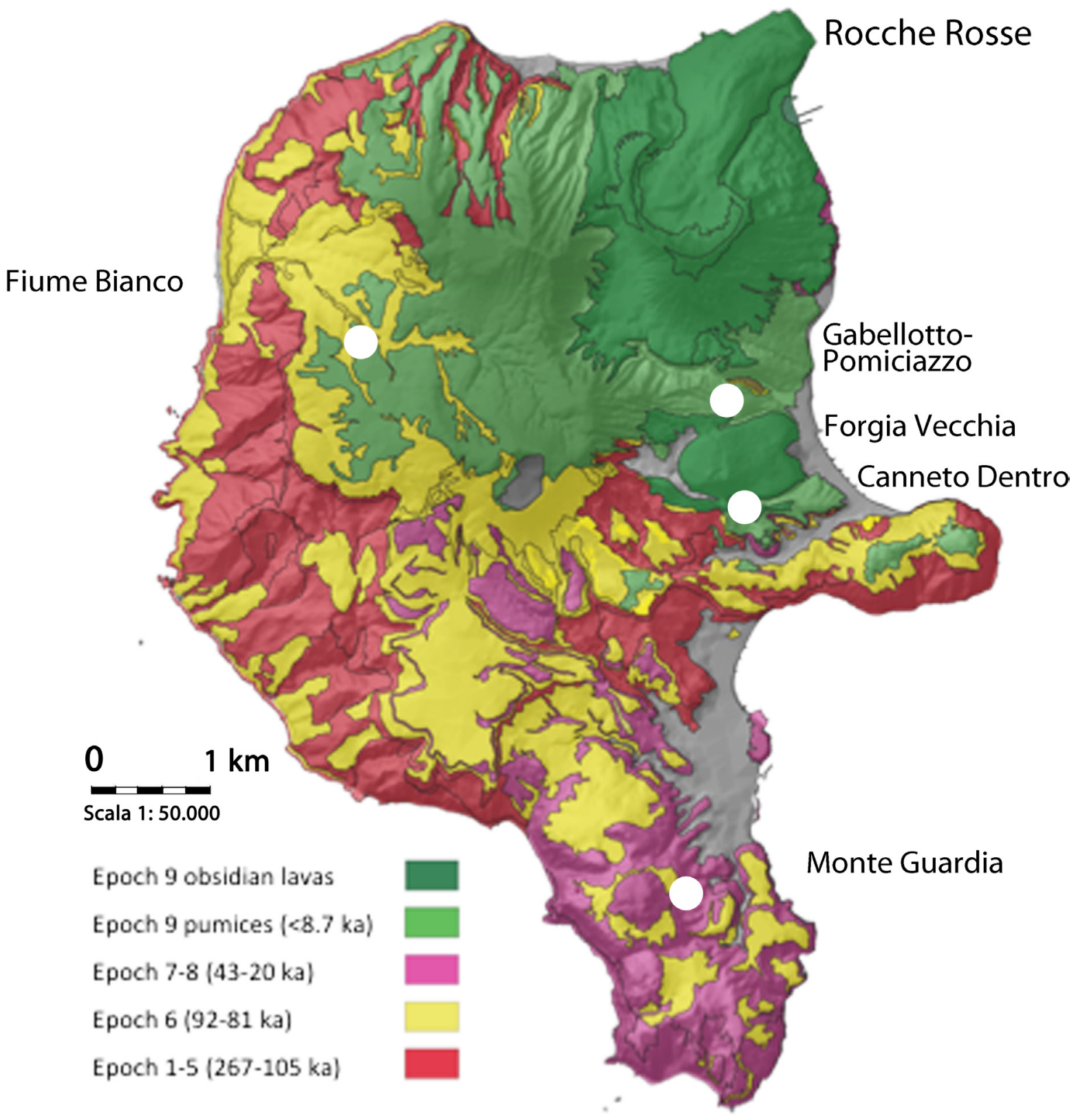

Figure 3: Geological sketch map of Lipari island (modified after Forni et al., 2013); sampling sites of geological samples, white dots on the map. 


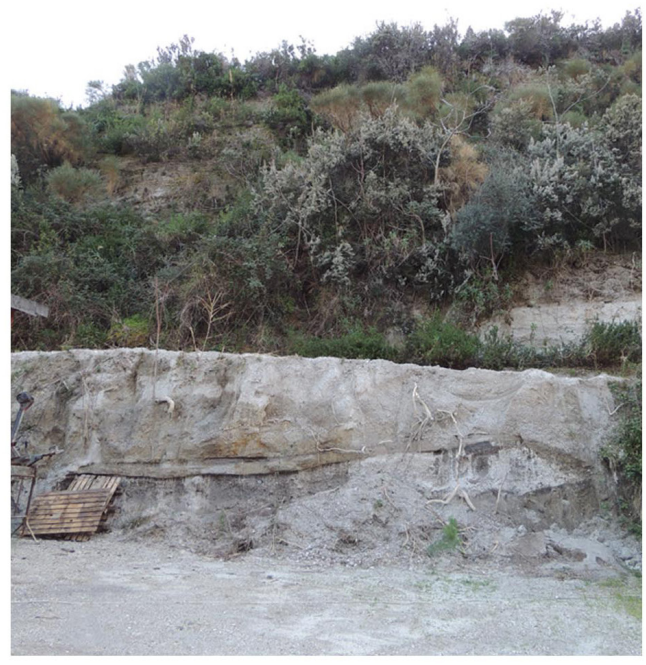

1

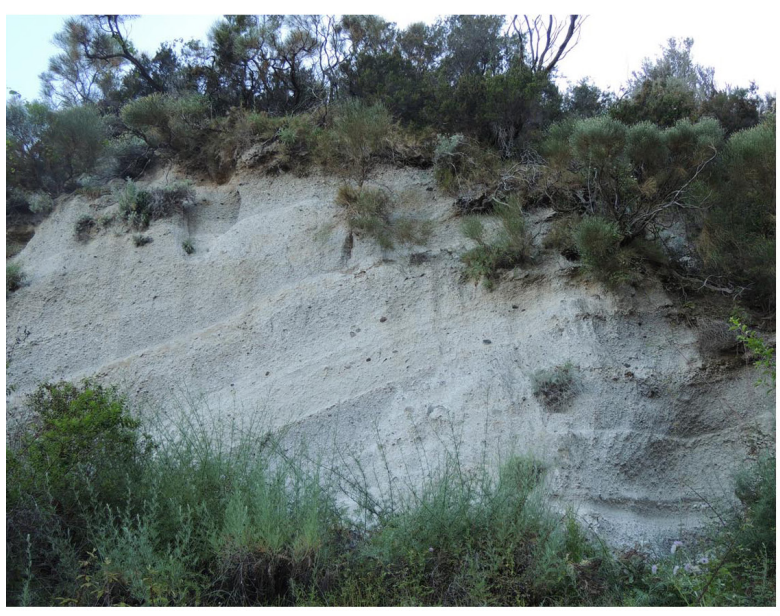

3

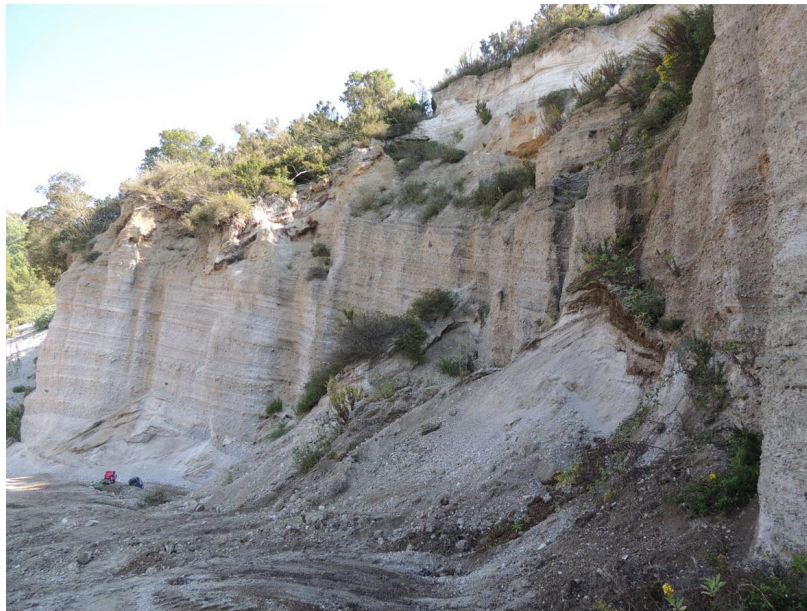

5
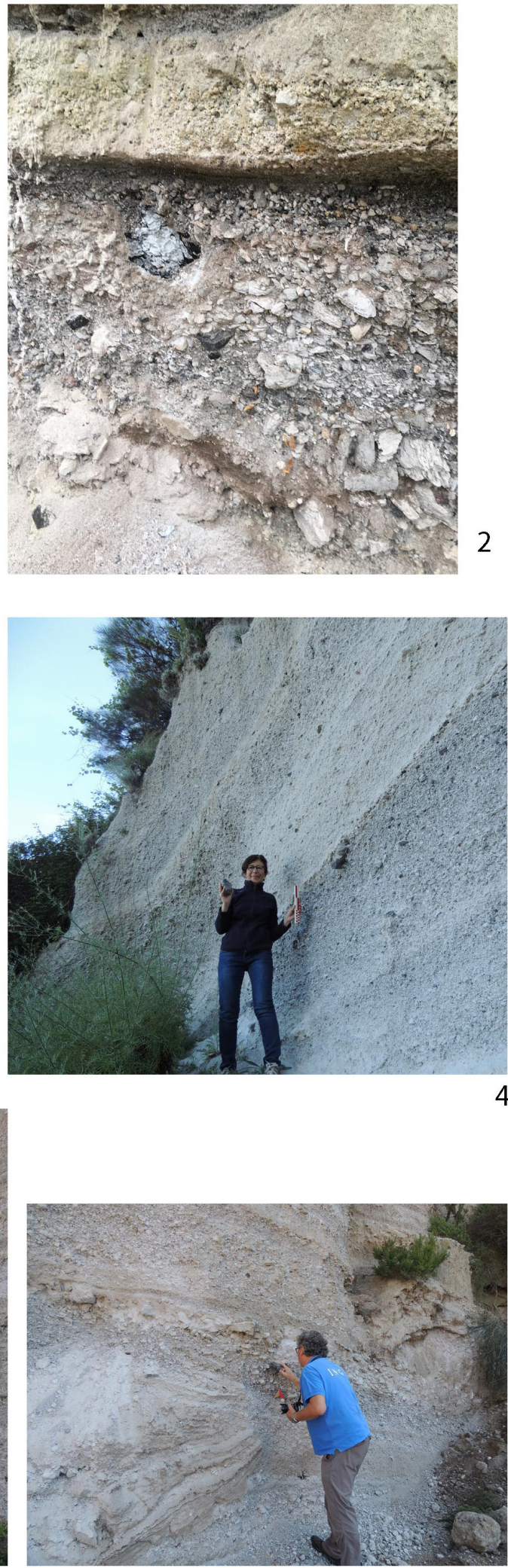

6

Figure 4: Lipari. Places of collected geological samples: 1-2) Canneto Dentro; 3-4) Vallone del Gabellotto; 5-6) Vallone Fiume Bianco. 
Table 1: Geological samples.

\begin{tabular}{lll}
\hline & Coordinate GPS & Numero campione \\
\hline Vallone Fiume Bianco & $38^{\circ} 29^{\prime} 44^{\prime \prime} \mathrm{N} ; 14^{\circ} 56^{\prime} 2^{\prime \prime} \mathrm{E}$ & LIP4 e LIP4A \\
Cava Fiume Bianco & $38^{\circ} 49^{\prime} 95^{\prime \prime} \mathrm{N} ;$ 14 $^{\circ} 93^{\prime}$ '03”' E & LIP6 e LIP6A \\
Canneto Dentro & $38^{\circ} 29^{\prime} 1^{\prime \prime} \mathrm{N} ; 14^{\circ} 57^{\prime} 37^{\prime \prime} \mathrm{E}$ & LIP3 e LIP3A \\
Pomiciazzo-Gabellotto & $38^{\circ} 49^{\prime} 50^{\prime \prime} \mathrm{N} ; 14^{\circ} 95^{\prime} 69^{\prime}$ ' E & LIP7 e LIP8 \\
\hline
\end{tabular}

The second group includes some waste artefacts (splinters and blades) found in the Neolithic settlements: Facies Stentinello 5500-5000 BC: sites Castellaro (Lipari) and Rinicedda (Salina); Facies Diana 4500-4000 BC: site Contrada Diana (Lipari).

\section{Discussion}

This research project has two main objectives. The first is to better define the internal mobility of the Neolithic communities and the paths towards the source of supply, in relation to the different chronological phases. For this objective, geological sampling can be related to the human settlements distributed on the territory (fig. 2). We don't, and can't know if some of them also occurred in the northern area of Lipari, where the identification of obsidian quarries or collection sites exploited during the Neolithic period is due to occasional findings, because the whole area has been covered by recent volcanic eruptions of Monte Pilato. The discovery of soils with remains of fireplace suggests that collection and extraction sites existed near the source. Since the occurrence of obsidian on Lipari was the main reason for its human colonisation, some remarks can be made on the characteristics of the landscape that led the first communities to choose certain places instead of others (Martinelli et al., in press). Flat areas for agriculture and water sources were certainly the primary conditions, but in the case of Lipari also the proximity to areas with raw materials played a significant role. For the inhabitants of Castellaro, the collection of obsidian blocks from pumice-rich pyroclastic deposit of the Vallone Fiume Bianco had to be much easier than extracting blocks directly from the compact lava flow. The natural erosion of these pyroclastic deposits, due to rainwater, probably started by removing the pumice, much lighter and floating, then leaving the obsidian blocks on the Fiume Bianco stream bed. It would also explain the presence of the settlement Rinicedda on the island of Salina, found in front of the coast of Lipari where the Fiume Bianco stream descends towards Timpone Ospedale and then flows into the sea. Changes of the coastline (Lambeck et al., 2004) due to erosion and to sea level rise hinder the recognition of the landing points from which the inhabitants of Salina could reach the obsidian sources. We also cannot rule out that obsidian blocks were available on the coast at the mouth of the Fiume Bianco stream, transported down to the coast from the river during floods, and then easily available for people coming from Rinicedda.

Another way is suggested by a new dating of charcoal (table 2) found by Keller in 1969 in the paleo soil above the Vallone del Gabellotto formation (Cavalier, 1979, p. 123). The dating suggests the attendance during the most ancient phase of the Aeolian Neolithic. Castellaro's people reached this part of the island through an internal route to exploit the western side of the Pomiciazzo lava or, more likely, collecting the obsidian blocks from pyroclastic deposits of the Vallone del Gabellotto. The erosion of these deposits was at the beginning and therefore the depth of the valley was much less than it is today. The passage could take place through the saddle between Colle S. Elmo and Monte Chirica, likely easier than nowadays (Cavalier ,1979 p. 126). In fact, up to the beginning of the 1900s the Pomiciazzo locality near Lami was linked to Pirrera - Sant'Elmo by a little portion of the tuff ring of the prehistoric volcano, crossing Vallone Gabellotto like a bridge, now completely eroded by the canyon.

Two radiocarbon dates made for the Middle Neolithic period attested the arrival of the first stable communities between 5500 and $5000 \mathrm{BC}$ (table 2). 
Table 2: Neolithic sites of the Stentinello facies and radiocarbon dating.

\begin{tabular}{|c|c|c|c|c|}
\hline Lab Code - Year & Archaeological report & Sample & Dated BP & $\begin{array}{l}\text { Dated BC calibrated } \\
(95,4 \%)\end{array}$ \\
\hline LTL4329A - 2009 & $\begin{array}{l}\text { Salina: Rinicedda US6 tg. } 4 \\
\text { (year 2009) }\end{array}$ & $\begin{array}{l}\text { charcoal Erica cfr. } \\
\text { arborea }\end{array}$ & $6325 \pm 45$ & $5381-5214$ \\
\hline Beta $548576-2019$ & $\begin{array}{l}\text { Lipari: paleosoil of obsidian } \\
\text { quarry (year 1970) }\end{array}$ & charcoal & $\begin{array}{l}6290 \pm 30 \\
7269-7166 \mathrm{cal}\end{array}$ & $5320-5217 \mathrm{BC}$ \\
\hline
\end{tabular}

The second objective concerns the chronology of the stratigraphic units of Canneto Dentro, Vallone del Gabellotto-Fiume Bianco, and the Pomiciazzo lava flow through the age determination of the obsidian samples with the fission-track dating. To reach this goal, we analyzed both raw materials from different geological units and artefacts from Neolithic settlements on the Aeolian islands. Obsidian samples were divided into two fractions, one of which was irradiated from a reactor core at the TRIGA Mark II Research Nuclear Reactor of the LENA Laboratory (University of Pavia, Italy). The irradiated and non-irradiated fraction of obsidian samples were then prepared for etching and microscope observation, applying the standard technique consisting of mounting samples in epoxy resin. Etching was performed with HF in monitored conditions, and samples were observed with total 500x magnification for identification and counting of spontaneous and induced fission track. This procedure aims to get the density of (natural) fossil and (artificial), from reactor neutron induced tracks and, therefore, the cooling age of obsidian sources and artefacts. We are still working to achieve this part of the research.

\section{Preliminary Results}

The time required to complete the research is dependent on many variables, including the difficulty to confidently determine the tracks of fission. At present we can show some preliminary results concerning Lipari obsidian. The continuous relationship between the exploitation of the raw material and the Neolithic communities began on the Aeolian Island in the second half of the 6th millennium BC. The comparison between the oldest Neolithic sites in Sicily and in the Italian peninsula will be interesting to verify if the spread of obsidian begun before its management was undertaken by resident communities (Freund et al., 2015, 2017). During the Stentinello facies we take into consideration the occurrence of two probable ways to access the source: a direct route to the pyroclastic deposits of Vallone Fiume Bianco, that could be used by land from the Castellaro site or by sea from the Rinicedda site in Salina; another route could have crossed Vallone del Gabellotto towards the obsidian flow of Pomiciazzo (fig. 2). In the latter case, the morphological differences of the local topography, compared to the current time were considerable: for instance, strong eruptions occurred in the historical time have covered the north-east part of Lipari (Forni et al., 2013), also causing a strong erosion of their products. The same phenomena have affected the Canneto Dentro site, largely covered by the eruption of Forgia Vecchia that might have eliminated any anthropic traces. In the subsequent Neolithic facies (Tricromica, Serra d'Alto and Diana) that inhabited the Rocca of Lipari and the basal plain of Contrada Diana, the inhabitants chose the route by sea that allowed them to land directly on the east side of island and to exploit obsidian blocks from the flow near the coast (fig. 2), or collecting them from pyroclastic deposits of the Vallone del Gabellotto but also from the nearby Canneto Dentro (Tykot et al., 2013; Tykot, 2019). A pottery fragment of Diana's facies was found in the Papesca site, one of the two quarry points known. Rocca was probably chosen as a settlement for its defensive purposes and so the inhabitants could easily reach the eastern part of the island where raw materials could be found.

Acknowledgments: We are very grateful to architect Rosario Vilardo, director of the Aeolian Islands Archaeological Park for research support; to Sara T. Levi, Dept. of Classical and Oriental Studies, Hunter College-University of New York and director of the Stromboli research, to collaboration for dating C14. A first thesis in Sciences for the Conservation and Diagnostics of Cultural Heritage was carried out at the University of Milan in 2019/2020, under the supervision of Letizia Bonizzoni and Alessandra Guglielmetti. Unfortunately, the COVID19 emergency has not allowed a final review of the results and they are therefore to be considered very preliminary. 


\section{References}

Acquafredda, P., Andriani, T., Lorenzoni, S., \& Zanettin, E. (1999). Chemical characterization of obsidian from different sources by non distructive SEM-EDS analytical method. Journal of Archaeological Science, 26(3), 315-325. https://doi.org/10.1006/jasc.1998.0372

Acquafredda, P., Muntoni, I. M., \& Pallara, M. (2006). La determinazione di provenienza dell'ossidiana mediante SEM+EDS: caratteristiche della metodica e casi studio dall'Italia sud-orientale. Atti XXXIX Riunione Scientifica Istituto Italiano di Preistoria e Protostoria, Materie prime e scambi nella preistoria italiana, (pp. 509-519). Firenze: Istituto Italiano di Preistoria e Protostoria.

Acquafredda, P., Muntoni, I. M., \& Pallara, M. (2016). La provenienza dell'ossidiana nel Neolitico della Puglia. Atti XLVII Riunione Scientifica Preistoria e Protostoria della Puglia, Studi di Preistoria e Protostoria 4 (pp. 809-814). Firenze: Istituto Italiano di Preistoria e Protostoria.

Acquafredda, P., Muntoni, I. M., \& Pallara, M. (2018). Reassessment of WD-XRF method for obsidian provenance shareable databases. Quaternary International, 468, 169-178. https://doi.org/10.1016/j.quaint.2017.08.020

Arias, C., Bigazzi, G., Bonadonna, F. P., Cipollini, M., Hadler, J. C., Lattes, C. M. G., \& Radi, G. (1986). Fission-track dating in archaeology: a useful application. In P. Parrini (Ed.). Scientific Methodologies Applied to Works of Art. Proceedings of the Symposium, Florence, Italy, 2-5 May 1984 (pp. 151-159). Montedison, Progetto Cultura, Milano.

Arias-Radi, G., Bigazzi, G., \& Bonadonna, F. (1972). Le tracce di fissione. Un metodo per lo studio delle vie di commercio dell'ossidiana. Origini, VI, 155-169.

Barca, D., De Francesco, A.M. \& Mirocle Crisci, G. (2007). Application of Laser Ablation ICP-MS for characterization of obsidian fragments from peri-Tyrrhenian area. Journal of cultural Hermitage, 8(2), 141-150. https://doi.org/10.1016/j.culher.2006.12.001

Belluomini, G. (1972). Studi sulle ossidiane italiane: Caratterizzazione geochimica e datazione. Geo-Archeologia, 1, 9-21.

Bernabò Brea, L., \& Cavalier, M. (1960). La stazione preistorica della contrada Diana e la necropoli protostorica di Lipari. Meligunis Lipara I. Palermo: Flaccovio.

Bernabò Brea, L., \& Cavalier, M. (1995). Salina. Ricerche archeologiche (1989-1993). Palermo: Meligunis Lipara VIII, Accademia di Scienze Lettere e Arti, Regione Siciliana, Assessorato dei Beni Culturali.

Bigazzi, G., \& Bonadonna, F. (1973). Fission Track Dating of the Obsidian of Lipari Island (Italy). Nature, 242(5396), 322-323. https://doi. org $/ 10.1038 / 242322 \mathrm{a} 0$

Bigazzi, G., Bonadonna, F.P., Belluomini, G.\& Malpieri, L. (1971). Studi sulle ossidiane italiane. IV. Datazione con il metodo delle tracce di fissione. Bollettino Società Geologica Italiana, 90, 469-480.

Bigazzi, G., Coltelli, M., \& Norelli, P. (2003). Nuove età delle ossidiane di Lipari determinate con il metodo delle tracce di fissione. In Geoltalia, 4 Forum Italiano di Scienze della Terra, riassunti, sessione 12, (pp. 444-446). Bellaria.

Bigazzi, G., Meloni, S., Oddone, M., \& Radi, G. (1986). Provenance studies of obsidian artifacts: Trace element analysis and data reductionm. Journal of Radioanalytical and Nuclear Chemistry, 98(2), 353-363. https://doi.org/10.1007/BF02037098

Bigazzi, G., Meloni, S., Oddone, M., \& Radi, G. (1992). Nuovi dati sulla diffusione dell'ossidiana negli insediamenti preistorici italiani. In Herring, E., Whitehouse, R., \& Wilkins, J. (Eds.), Papers of the Fourth Conference of Italian Archaeology (Vol. 1, Part 1, pp. 9-18). London, Accordia Research Centre.

Bigazzi, G., Oddone, M., \& Radi, G. (2005). The Italian obsidian sources. Archeometriai Mühely, 1(1), 1-13.

Bigazzi, G., \& Radi, G. (1981). Datazione con le tracce di fissione per l'identificazione della provenienza dei manufatti di ossidiana. Rivista di Scienze Preistoriche, XXXVI, 223-250.

Buchner, G. (1949). Ricerche sui giacimenti e sulle industrie di ossidiana in Italia. Rivista di Scienze Preistoriche, IV, 162-186.

Cann, J., \& Renfrew, C. (1964). The Characterization of Obsidian and its application to the Mediterranean Region. Proceedings of the Prehistoric Society, 30, 111-133. https://doi.org/10.1017/S0079497X00015097

Cavalier, M. (1979). Ricerche preistoriche nell'arcipelago eoliano. Rivista di Scienze Preistoriche, XXXIV(1-2), 45-135.

Cavalier, M. (1997). Obsidian and the Aeolian islands. In M. Cortini \& B. De Vivo (Ed.), Volcanism and Archaeology of the Mediterranean Area, Research Signpost, (pp. 101-106). Trivandrum, India.

Cortese, M., Frazzetta, G., \& La Volpe, L. (1986). Volcanic history of Lipari (Aeolian Islands, Italy) during the last 10,000 years. Journal of Volcanology and Geothermal Research, 27, 117-133.

Gamberi, F., \& Marani, M. P. (1997). Detailed Bathymetric Mapping of the Eastern Offshore Slope of Lipari Island (Tyrrhenian Sea): Insight into the Dark Side of an Arc Volcano. Marine Geophysical Researches, 19(4), 363-377. https://doi.org/10.1023/A:1004262602101

Forni, F., Lucchi, F., Peccerillo, A., Tranne, C.A., Rossi, P.L. \& Frezzotti, M. L. (2013). Stratigraphy and geological evolution of the Lipari volcanic complex (central Aeolian Archipelago). In F.Lucchi, A. Peccerillo, J. Keller, C.A. Tranne, \& P. L. Rossi (Eds.), The Aeolian Islands Volcanoes (pp. 213-279). London: The Geological Society. https://doi.org/10.1144/M37.10

Freund, K. P., Tykot, R. H., \& Vianello, A. (2015). Blade production and the consumption of obsidian in Stentinello period Neolithic Sicily. Comptes Rendus. Palévol, 14(3), 207-217. https://doi.org/10.1016/j.crpv.2015.02.006

Freund, K. P., Tykot, R. H., \& Vianello, A. (2017). Contextualizing the Role of Obsidian in Chalcolithic Sicily (c. 3500 - 2500 BC). Lithic Technology, 42(1), 35-48. https://doi.org/10.1080/01977261.2017.1290335

Keller, J. (1967). After und abfolge der vulkanischen Ereignisse auf den Aolischen Inseln. Berichte der Naturforschenden Gesellschaft zur Freiburg, 57, 33-67.

Keller, J. (1970). Datierung der Obsidiane und Bimstuffe von Lipari. Neues Jahrbuch fur Geologie und Palaontologie: Monatshefte, 1, (pp. 90-101). Stuttgard. 
Lambeck, K., Antonioli, F., Purcell, A., \& Silenzi, L. (2004). Sea-level change along the Italian coast for the past 10,000 yr. Quaternary Science Reviews, 23(14-15), 1567-1598. https://doi.org/10.1016/j.quascirev.2004.02.009

Lucchi, F. Peccerillo, A., Keller, J., Tranne, C. A. \& Rossi, L. (Eds.). (2013). The Aeolian Islands Volcanoes (Geological Society Memoirs Vol. 37), The Geological Society, London.

Pichler, H. (1976). Carta geologica dell'isola di Lipari, Istituto di Vulcanologia. Firenze: CNR LAC.

Martinelli, M. C., Dawson, H., Lo Cascio, P., Levi, S. T., \& Fiorentino, G. (in press). “Blowin' in the Wind”: Settlement and Landscape Dynamics in the prehistory of the Aeolian Islands (Italy), Journal Mediterranean Archaeology.

Martinelli, M. C., \& Lo Cascio, P. (2018). Topografia della preistoria nelle Isole Eolie. In M. Bernabò Brea, M. Cultraro, M. Gras, M. C. Martinelli, C. Pouzadoux, \& U. Spigo (Eds.), A Madeliene Cavalier (pp. 65-78). Napoli: Centre Jean Berard.

Martinelli, M. C., Tykot, R. H., \& Vianello, A. (2019). Lipari (Aeolian Islands). Obsidian in the Late Neolithic. Artifacts, supply and function. Open Archaeology, 5(1), 46-64. https://doi.org/10.1515/opar-2019-0005

Nomi, F., \& Speciale, C. (2017). Castellaro (Lipari, ME). Notiziario di preistoria e protostoria, Istituto Italiano di Preistoria e Protostoria, 4.III, 87-90. www.iipp.it

Tykot, R. H. (1996). Obsidian Procurement and Distribution in the Central and Western Mediterranean. Journal of Mediterranean Archaeology, 9(1), 39-82. https://doi.org/10.1558/jmea.v9i1.39

Tykot, R.H. (1998). Mediterranean Islands and Multiple Flows: The Sources and Exploitation of Sardinian Obsidian. In M. S. Shackley (Ed.), Archaeological Obsidian Studies: Method and Theory (pp. 67-82). New York, Plenum Press.

Tykot, R.H. (2002a). New Approaches to the Characterization and Interpretation of Obsidian from the Mediterranean Island Sources. In P. B. Vandiver, M. Goodway, J. R. Druzik, \& J. L. Mass (Eds.). Materials Issues in Art and Archaeology VI: Symposium held November 26-30, 2001, Boston, Massachusetts, USA, Materials Research Society Symposium Proceedings Volume 712 (pp. 143-157). Warrendale, Pennsylvania: Materials Research Society.

Tykot, R. H. (2002b). Chemical fingerprinting and source tracing of obsidian: The central Mediterranean trade in black gold. Accounts of Chemical Research, 35(8), 618-627. https://doi.org/10.1021/ar000208p PMID:12186566

Tykot, R. H. (2004). L'esatta provenienza dell'ossidiana e i modelli di diffusione nel mediterraneo centrale durante il Neolitico. In P. Castelli et al. (Eds.) Atti del convegno L'ossidiana del Monte Arci nel Mediterraneo: recupero dei valori di un territorio, 29-30 novembre e 1 dicembre 2002, Pau (pp. 118-132). Cagliari.

Tykot, R. H. (2017). Obsidian Studies in the Prehistoric Central Mediterranean: After 50 Years, What Have We Learned and What Still Needs to Be Done. Open Archaeology, 3(1), 264-278. https://doi.org/10.1515/opar-2017-0018

Tykot, R. H. (2019). Geological Sources of Obsidian on Lipari and Artifact Production and Distribution in the Neolithic and Bronze Age Central Mediterranean. Open Archaeology, 5(1), 83-105. https://doi.org/10.1515/opar-2019-0007

Tykot, R. H., \& Ammerman, A. J. (1997). New Directions in Central Mediterranean Obsidian Studies. Antiquity, 71(274), 1000-1006. https:// doi.org/10.1017/S0003598X00085896

Tykot, R. H., Freund, K. P., \& Vianello, A. (2013). Source Analysis of Prehistoric Obsidian Artifacts in Sicily (Italy) using pXRF. In R. A. Armitage \& J. H. Burton (Eds.), Archaeological Chemistry VIII. (ACS Symposium Series, Vol. 1147, pp. 195-210). American Chemical Society. https://doi.org/10.1021/bk-2013-1147.ch011

Zanchetta, G., Sulpizio, R., Roberts, N., Cioni, R., Eastwood, W. J., Siani, G., . . Santacroce, R. (2011). Tephrostratigraphy, chronology and climatic events of the Mediterranean basin during the Holocene: An overview. The Holocene, 21(1), 33-52. https://doi. org/10.1177/0959683610377531

Wagner, G. A., Storzer, C., \& Keller, J. (1976). Spaltspurendatierung quartaäer Gesteinsgläser aus dem Mittelmeerraum. Neues Jahrbuch für Mineralogie Monatshefte, 2, 84-94. 